\title{
Congenital Diaphragmatic Hernia: Comparison of Animal Models and Relevance to the Human Situation
}

\author{
Rhiannon B. van Loenhout ${ }^{a, b}$ Dick Tibboel ${ }^{b}$ Martin Post ${ }^{a} \quad$ Richard Keijzer $^{a}, b$ \\ a Program in Physiology and Experimental Medicine, Hospital for Sick Children, Toronto, Ont., Canada; \\ ${ }^{b}$ Department of Pediatric Surgery, Erasmus MC-Sophia, Rotterdam, The Netherlands
}

\section{Key Words}

$\mathrm{CDH} \cdot$ Pulmonary hypoplasia $\cdot$ Transgenics $\cdot$ Nitrofen $\cdot$

Retinoids · Surgery

\begin{abstract}
Congenital diaphragmatic hernia (CDH) occurs in 1 in 3,000 newborns. Mortality and morbidity are due to the amount of pulmonary hypoplasia $(\mathrm{PH})$, the response on artificial ventilation and the presence of therapy-resistant pulmonary hypertension. The pathogenesis and etiology of $\mathrm{CDH}$ and its associated anomalies are still largely unknown despite all research efforts over the past years. Several animal models have been proposed to study $\mathrm{CDH}$. In this review we compare surgical, pharmacological and transgenic models, and discuss their strengths and limitations to study PH.
\end{abstract}

Copyright $\odot 2009$ S. Karger AG, Basel

\section{Introduction}

Congenital diaphragmatic hernia $(\mathrm{CDH})$, a developmental defect of the diaphragm, has a prevalence of 1 in 2,000-3,000 newborns and accounts for approximately $8 \%$ of the known major congenital anomalies [1]. In humans, three different types of hernia can be distinguished: a posterolateral Bochdalek type (about $70 \%$ of the cases), an anterior Morgagni type (about $27 \%$ of the cases) and a central hernia, septum transversum type (about 2-3\% of the cases). Eighty-five percent of the hernias occur on the left side, $13 \%$ on the right and only $2 \%$ are bilateral [reviewed in 2-4]. Children with a CDH suffer from a substantial amount of morbidity and mortality due to the associated abnormal pulmonary development resulting in two clinical problems: pulmonary hypoplasia $(\mathrm{PH})$ and persistent pulmonary hypertension. Both conditions are present to a variable extent in patients with $\mathrm{CDH}$ and despite the fact that recent progress in the care of these children has resulted in survival rates of up to $90 \%$ in some tertiary-care centers, these measures have not led to a lower morbidity [5]. However, due to the absence of sufficient lung-protective strategies, most of the newer treatment modalities have replaced mortality with a higher morbidity. The problem with these new treatment modalities such as high-frequency oscillation and/or inhaled nitric oxide and extracorporeal membrane oxygenation, is that they are designed for treating the sequelae of $\mathrm{CDH}$, $\mathrm{PH}$ and persistent pulmonary hypertension and do not contribute to the prevention of these conditions. Moreover, prevention is not possible without a sound understanding of the etiology and pathogenesis of $\mathrm{CDH}$. Essential elements required for a better understanding of this anomaly, notably how the different clinical problems relate to each other, are still lacking. A basic understand-

\section{KARGER}

Fax +41613061234 E-Mail karger@karger.ch www.karger.com
(C) 2009 S. Karger AG, Basel

1661-7800/09/0963-0137\$26.00/0

Accessible online at:

www.karger.com/neo
Richard Keijzer, MD, PhD, MSc

Erasmus MC-Sophia, Room SK-1254

Dr Molewaterplein 60

NL-3015 GJ Rotterdam (The Netherlands)

Tel. +31 10704 6783, Fax +31 10703 6802, E-Mail r.keijzer@erasmusmc.nl 
ing of how a $\mathrm{CDH}$ arises together with $\mathrm{PH}$ and persistent pulmonary hypertension is fundamental in our quest for new answers on how to protect these children from the sequelae of this anomaly. Furthermore, it may aid in finding ways to modulate the natural course in a prenatally diagnosed baby in the near future [6].

Animal models available to study $\mathrm{CDH}$ include a surgical model in the rabbit and sheep, a pharmacological (nitrofen) model in the rat and mouse, and genetic (knockout) mouse models. In this review we will describe these three models and specifically focus on $\mathrm{PH}$, address their differences and discuss their relevance to human $\mathrm{CDH}$.

\section{Surgical Models}

One of the hypotheses concerning the pathogenesis of $\mathrm{PH}$ in $\mathrm{CDH}$ is that it results from the intrathoracic herniation of the abdominal viscera, thereby compromising pulmonary development. Fetal breathing movements are impaired and, therefore, normal development of the lungs is hampered. Based on this idea, the first surgical animal models were created to study both lung pathogenesis and rescue options. The most commonly used surgical models use sheep and rabbits.

The sheep model was introduced by Delorimier et al. [7] in 1967. The hernia is surgically created at gestational days $72-75$ (term is $145-149$ days). The abdominal bowel is positioned into the chest to optimally mimic human $\mathrm{CDH}$. Gestational days $72-75$ in sheep are equivalent to a gestational age of 10 weeks in humans. This is the pseudoglandular stage of lung development: the moment of pleuroperitoneal canal fusion during diaphragmatic development [8]. Later, a similar surgical model was developed in rabbits. Advantages of the rabbit model over the sheep model are its shorter gestational period (term is 31 days with the hernia created at day 23), the larger litter size, easy availability and lower costs $[9,10]$.

Surgical models are mainly suitable to investigate interventional strategies in $\mathrm{CDH}$. Examples of investigated interventions are administration of corticosteroids, in utero repair of the diaphragmatic defect and fetal tracheal occlusion or a combination of the two $[11,12]$. In utero repair has been attempted with either primary closure of the defect by using a patch (immediate reduction) or secondary closure by using the slow 'silo' reduction technique in which the opening gradually reduces as the fetus grows [13-15]. After successful in utero repair of induced $\mathrm{CDH}$ in animal models, including nonhuman primates, Harrison et al. [14] performed the first human surgical repair in utero. Unfortunately, it quickly became clear that there was no improvement in survival and, moreover, an increase in premature delivery was observed.

Later, tracheal ligation or clipping was developed with the aim to gradually reposition the abdominal viscera back into the abdomen [16-18]. The rationale was based on the observation that children with a prenatal airway obstruction have hyperplastic lungs [19]. Preventing lung fluid efflux exerts a build-up pressure in the thoracic cavity that repositions the abdominal viscera back in the abdomen. Di Fiori et al. [17] demonstrated that tracheal ligation reversed the effects of surgically induced $\mathrm{PH}$ in fetal sheep. Unfortunately, the results of human trials on this ex-utero intrapartum treatment technique with clipping were disappointing even when a minimally invasive approach was used. Again premature delivery appeared to be the problem [20-22]. Later the 'plug the lung until it grows' method was developed in lambs. Endoscopically, an inflatable balloon is inserted through the fetal mouth in the trachea through a catheter, which then is filled with saline and kept in place for several days [2328]. A tracheal occlusion trial in humans in North-America demonstrated no differences in survival when compared to controls. The authors blamed this on an improvement in survival in the control group due to increased care in a specialized center [22]. However, Deprest et al. $[29,30]$ stated that a great part of the enrolled patients were likely to have survived without treatment based on the 'lung area to head circumference ratio' risk assessment. Exclusively, the most severe $\mathrm{CDH}$ cases were enrolled in a European study and underwent the fetoscopic endoluminal tracheal occlusion (FETO) procedure. This study demonstrated up to $64 \%$ survival in comparison to $8 \%$ survival of nontreated comparable $\mathrm{CDH}$ patients, and thus appeared to be very promising $[29,31-33]$. The same group demonstrated similar results in a more homogeneous group a year later [34]. Premature rupture of the membranes, with the risk of premature delivery, appeared to be a common complication, but in a more recent study it was shown that there was an increase to $75 \%$ of deliveries after 34 weeks when FETO was performed due to improved experience. The most recent publication demonstrated a survival rate of $50 \%$, with a higher neonatal survival with prenatal balloon removal in comparison to perinatal removal [33]. It was also demonstrated that lung volume before and lung response after FETO are important survival predictors $[35,36]$. At this moment, the FETO task force is working on permission to start a randomized controlled trial to better validate these preliminary results $[33,37]$. 
Tracheal occlusion in surgical models has not only been shown to improve $\mathrm{PH}$, but pulmonary vascular abnormalities also benefit from this procedure. For instance, tracheal occlusion studies in fetal sheep with a surgically induced diaphragmatic hernia demonstrated thinning of the pulmonary artery, correction of the abnormal muscularization of pulmonary arterioles, and a decrease in vessel resistance in the left pulmonary artery with maternal hyperoxia as seen in normal fetal sheep at term [38-40]. Similar positive effects of tracheal occlusion on pulmonary vascular development have been demonstrated in the surgical rabbit model [28]. Both surgical models are useful to study pulmonary vascular abnormalities in CDH [41-43].

Surgical models are based on a surgical intervention making a diaphragmatic defect in fetal rabbits and sheep $[44,45]$. This CDH model has proven especially useful in investigating interventional therapies such as the administration of corticosteroids, in utero repair of the diaphragmatic defect and tracheal occlusion [46, 47]. Unfortunately, the diaphragmatic defect is created relatively late in gestation and certain pulmonary changes seen in human $\mathrm{CDH}$ might have occurred prior to this time. Therefore, no information about the cause and early pathogenesis of the lung hypoplasia can be obtained with this model. Moreover, it is a uni-hit lung hypoplasia model while evidence suggests that a dual-hit might be responsible for the hypoplasia [48]. On top of that, a lot of the other associated anomalies (such as cardiac anomalies) cannot be studied in this model.

In summary, surgical animal models are useful in investigating interventional therapies, but are less instructive in studying the etiology and pathogenesis of $\mathrm{CDH}$. Interventional studies in this model have resulted in the incorporation of new prenatal techniques in human fetuses, with very promising results so far.

\section{Nitrofen Model}

The nitrofen model has been used for the past two decades to investigate the anomalies in $\mathrm{CDH}$. Originally, nitrofen (2,4-dichlorophenyl-p-nitrophenyl ether) was used as a herbicide. In toxicology screens in adult rats, no apparent problems were observed, though administration during midgestation to pregnant dams appeared to cause developmental anomalies of the heart, lungs, diaphragm, and skeleton of the embryos $[49,50]$. Based on the latter findings, nitrofen has been investigated for its usefulness to simulate the anomalies of $\mathrm{CDH}$ in rodents.
Numerous groups including ours demonstrated that nitrofen induced diaphragmatic hernias that were strikingly similar to the human condition. The specific location and extent of the diaphragmatic defects were very comparable, but the similarities in the $\mathrm{CDH}$-associated anomalies, including $\mathrm{PH}$ and persistent pulmonary hypertension, and cardiovascular and skeletal defects, were impressive too [51-54]. When nitrofen is administered to pregnant rat dams on day 9 of gestation when normal lung (day 11 of gestation) and diaphragm development (day 13 of gestation) are just about to begin, approximately $70 \%$ of the offspring will develop CDHs and $100 \%, \mathrm{PH}$. Therefore, the nitrofen animal model, taking into account the obvious disadvantages of being a toxicological (animal) model, can serve as a good tool to investigate the pathogenesis and therapeutic options in $\mathrm{CDH}$ and its anomalies in rodents. Despite the extensive use of nitrofen as a herbicide in agriculture, its possible teratogenetic effects have never been shown to play a role in human $\mathrm{CDH}$.

The etiology of both human $\mathrm{CDH}$ and nitrofen-induced $\mathrm{CDH}$ in rodents has been connected to perturbations in the retinoid signaling pathway (fig. 1), although the exact underlying mechanism remains to be elucidated. The first evidence that $\mathrm{CDH}$ could be connected to perturbations in the retinoid signaling pathway was obtained already in 1941 by Andersen [55], who noted diaphragmatic hernias in embryos of pregnant rats on a vitamin-A-deficient diet. This effect of maternal vitamin A deficiency was confirmed by Wilson et al. [56] in 1953. More modern approaches using genetic manipulation in mice have shown that ablation of retinoic acid receptor (RAR) signaling during development indeed results in diaphragmatic hernias, $\mathrm{PH}$ and/or lung agenesis [57]. In humans, only one small clinical study $(n=7)$ demonstrated that newborns with $\mathrm{CDH}$ had lower levels of plasma retinol in cord blood than controls [58]. Subsequently, $\mathrm{CDH}$ has been observed in patients with deletions on the $15 q$ chromosome, which contains the encoding gene for a cellular retinoic acid binding protein (CRABP1), although so far mutation analysis in isolated $\mathrm{CDH}$ cases are negative [59-61]. In 2000, the dual-hit hypothesis was introduced. It explained $\mathrm{PH}$ in $\mathrm{CDH}$ as a result of two insults [48]. There is an early bilateral nitrofen-induced $\mathrm{PH}$ observed prior to closure of the diaphragm (first insult) $[62,63]$. The second insult is caused by herniation of the abdominal viscera into the thorax due to disrupted closure of the diaphragm and affects the ipsilateral lung only by interference with fetal breathing movements. Administration of retinoic acid (RA) to nitrofen-treated lung ex- 
Fig. 1. Schematic representation of the retinoid signaling pathway. Retinol binds STRA6 and is transferred into the cytoplasm. Retinol can either be stored as retinyl ester (RE) by LRAT or be converted into retinal by retinol dehydrogenase (ROLDH). Retinal is converted into RA by RALDH. RA can either remain in the cytoplasm to be metabolized by cytochrome p450 (Сyp) 26 enzymes, or bind to $\mathrm{RAR}$ or retinoid $\mathrm{X}$ receptor (RXR) to activate the RA response element (RARE) and thereby alter gene transcription. Pathways that might be influenced by the effects of nitrofen are indicated by arrows.

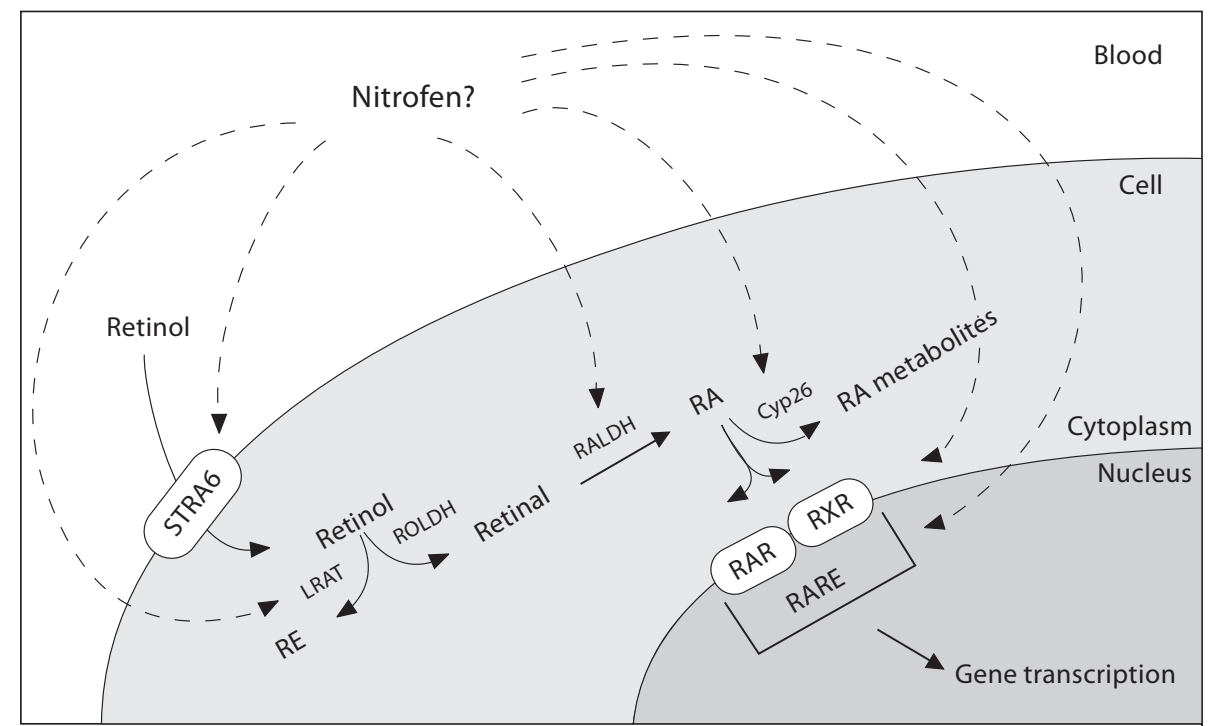

plants demonstrated an increase in lung growth and partially rescued the hypoplasia [64]. This observation was supported by Thebaud et al. $[65,66]$, who demonstrated an improvement in lung maturation and growth in nitrofen-treated embryos when the pregant dam was treated with vitamin A before, during or after nitrofen administration. In addition, survival of the fetuses improved in the vitamin-A-treated group [66]. Subsequently, administration of RA and vitamin A were compared in their effectiveness to reduce the number of hernias. In the untreated group the incidence of hernia was $54 \%$. With vitamin A treatment, the number of hernias was reduced to $32 \%$. RA demonstrated a reduction to $15 \%$ and with continuation of the RA feedings for up to 5 days, even a percentage of less than $10 \%$ was reached [67]. This supports the concept that both the diaphragmatic hernia and the $\mathrm{PH}$ result from a disruption in the retinoid signaling pathway.

Retinal dehydrogenase (RALDH) 2 is perceived to be the key enzyme in the RA synthetic pathway [68-70]. In vitro experiments have demonstrated that several agents (including nitrofen) responsible for the induction of diaphragmatic hernias, inhibit RALDH2 activity [71, 72]. Others have proposed that nitrofen interferes with the uptake of retinol by lung cells. Nitrofen-treated lungs have lower retinol levels while circulating retinol levels are increased in comparison to controls, in agreement with the idea of a disturbed retinol uptake [73]. Recently, STRA6 has been identified as the membrane receptor for serum retinol, and mutations in STRA6 result in dia- phragmatic hernias and $\mathrm{PH}$ amongst a variety of other anomalies [74-76]. However, nitrofen does not block the uptake of retinol by STRA6 [72]. Nitrofen treatment has been reported to downregulate the pulmonary retinol storage enzyme, lecithin:retinol acyltransferase (LRAT), and the RA-degrading enzyme Cyp26, while not affecting RALDH2 [42]. Since vitamin A deficiency experiments have shown similar decreases in RA-degrading enzymes and storage enzymes $[77,78]$, it is thought that this downregulation is due to low pulmonary retinol levels. Evidently, the exact mechanism by which nitrofen affects RA synthesis remains to be elucidated. It has also been suggested that nitrofen may compete with RA to bind to the RA receptor during embryogenesis, thereby impairing lung and diaphragm development $[66,79]$. In a twohybrid yeast assay nitrofen inhibited RAR and retinoid X receptor association only when very high embryonic lethal dosages were used [72]. In contrast, Chen et al. [80] demonstrated that nitrofen inhibits the activation of RA response elements in lacZ mice. RAR expression is not affected in $\mathrm{CDH}$. Rajatapiti et al. [81] reported that it was normal in human $\mathrm{CDH}$ lungs and in nitrofen-induced rat $\mathrm{CDH}$ lung tissue.

In summary, the retinoid signaling pathway is complex and it appears that a disruption anywhere in the pathway might be responsible for the morphological changes including $\mathrm{PH}$ seen in $\mathrm{CDH}$.

Besides the retinoid signaling pathway, another pathway implicated in $\mathrm{CDH}$ is the thyroid hormone signaling pathway (fig. 2) [82]. Nitrofen, triidothyronine $\left(\mathrm{T}_{3}\right)$ and 
Fig. 2. Schematic representation of the thyroid signaling pathway. Thyroid hormones $\mathrm{T}_{4}$ and $\mathrm{T}_{3}$ are produced in the thyroid gland. The hypothalamus produces thyrotropin-releasing hormone (TRH) which stimulates the pituitary gland to release thyroid-stimulating hormone (TSH) which for its part directly acts on the thyroid gland to stimulate $\mathrm{T}_{4}$ and $\mathrm{T}_{3}$ synthesis. At the target cells membrane passage is either carrier-mediated by thyroid hormone transporters (THT) or by diffusion. In the cell $\mathrm{T}_{4}$ is converted to $\mathrm{T}_{3}$ by deiodinases and binds to the nuclear TRs TR $\alpha$ and TR $\beta$. Through activation of the thyroid response element (TRE), gene expression is altered. Pathways that might be influenced by the effects of nitrofen are indicated by arrows.

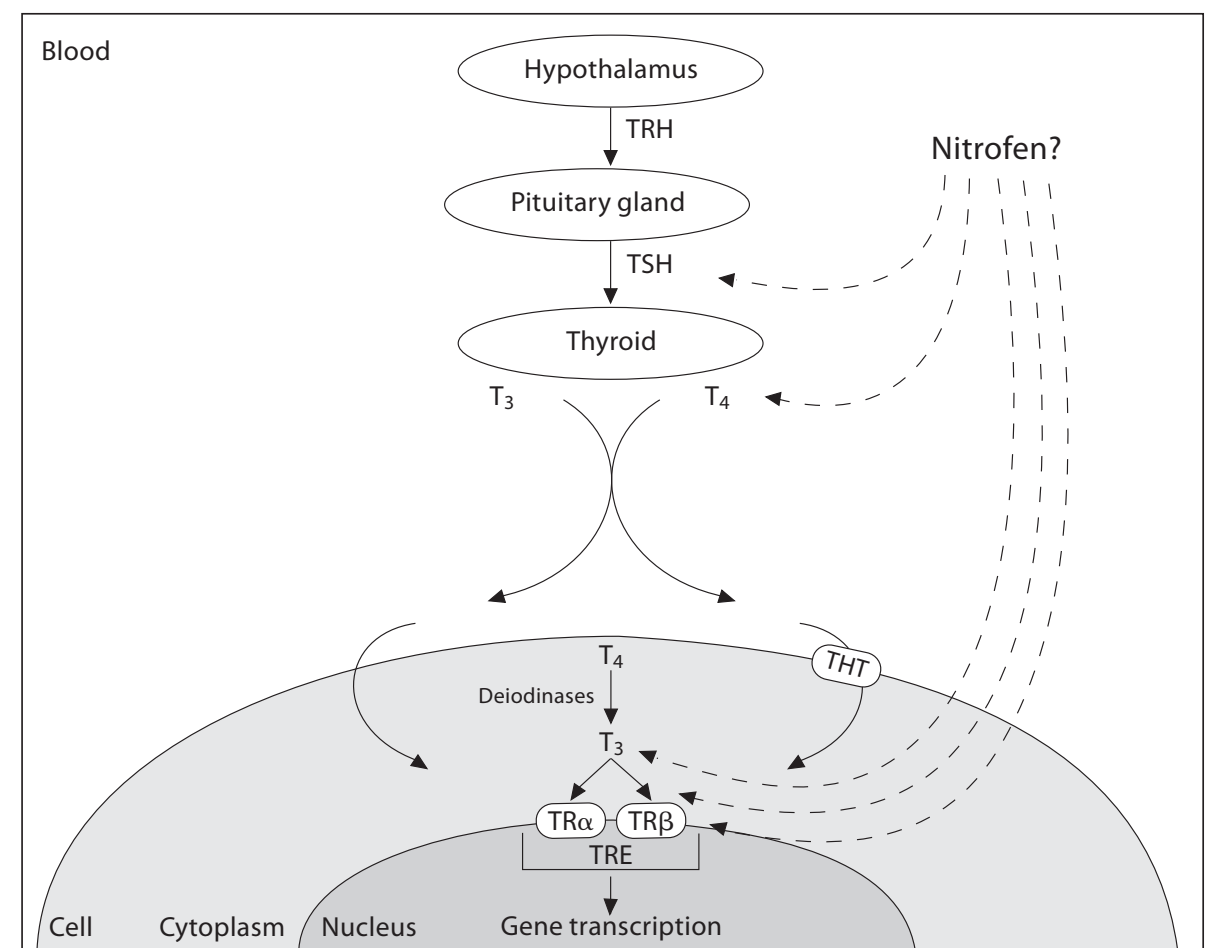

thyroxine $\left(\mathrm{T}_{4}\right)$ have similar chemical structures. All three are halogenated diphenyl ethers [83-85]. Thyroid hormones are important in lung morphogenesis [86-88]. Thyroid hormone receptors (TRs) are mostly expressed after gestational day 13 in the rat [89], but it has been demonstrated that very low levels of message are present at day 11 in the embryo [90]. Both $\mathrm{T}_{3}$ and $\mathrm{T}_{4}$ can cross the placenta during embryo morphogenesis in the rat from gestational day 9 onwards [91-93]. Therefore, it is possible that nitrofen influences both diaphragm formation and lung development by interfering with the thyroid hormone signaling pathway [72]. However, nitrofen-treated adult mice have decreased $\mathrm{T}_{4}$ levels while $\mathrm{T}_{3}$ levels remain normal [83]. In addition, fetuses of pregnant rats treated with nitrofen have lower circulating $\mathrm{T}_{3}$ and $\mathrm{T}_{4}$ levels, but pulmonary levels of $\mathrm{T}_{3}$ and $\mathrm{T}_{4}$ are not changed when compared to control fetuses [84, 94, 95]. If nitrofen exerts its action due to structural similarities with thyroid hormones (thyromimetica), it would be in a competitive manner. Nonetheless, Brandsma et al. [85] demonstrated that nitrofen inhibits binding of $\mathrm{T}_{3}$ to $\mathrm{TR} \alpha 1$ and TR $\beta 1$ in a noncompetitive manner by reducing the maximal binding capacity in vitro. In contrast, Noble et al. [72] found no perturbation in TR binding in the presence of nitrofen. When nitrofen and $\mathrm{T}_{4}$ were administered simultane- ously to thyroidectomized pregnant rats, the incidence of congenital anomalies in embryos dropped by $70 \%$ [84]. Despite this observation, coadministration of $\mathrm{T}_{4}$ and nitrofen did not reduce the percentage of $\mathrm{CDHs}$ [72].

Similar to RAR, TR $\alpha 1$ and TR $\beta 1$ belong to the steroid/ thyroid/retinoid receptor superfamily. Noble et al. [72] demonstrated that TR $\alpha 1$ and thyroid response element activity were not influenced by nitrofen in vitro. In vivo, however, nitrofen reduced the expression of TR $\alpha 1$ and TR $\beta 1$ in CDH rat lungs [96] without changing their cellular localization [81]. A similar decrease in TR $\alpha 1$ expression was noted in human $\mathrm{CDH}$-related hypoplastic lungs [81]. This decrease in TR $\alpha 1$ could lead to a diminished response to maternal thyroid hormone and later on (from gestational day 18 in rats) to the hormones produced by the fetus itself. In this way, lung morphogenesis might be affected by nitrofen [96]. As described earlier, Montedonico et al. [64] demonstrated a partial rescue by RA treatment in nitrofen-induced hypoplastic lung explants. The authors suggested that this might be only partial because downregulation in the thyroid hormone signaling pathway might also contribute to the PH. However, we should bear in mind that the role of thyroid hormones appears to be limited since in TR null mutant mice no apparent lung and diaphragm problems were observed and, there- 
fore, antenatal lung growth does not seem to be impaired by a lack of thyroid hormones [97]. In addition, van Tuyl et al. [98] demonstrated that both maternal and fetal hypothyroidism in transgenic mice did not alter prenatal lung development. Furthermore, there is great redundancy between the different TRs. Thus, while TR $\alpha 1$ levels are reduced in nitrofen-induced $\mathrm{CDH}$ rat lungs as well as human hypoplastic CDH lungs, the lack of both lung and diaphragm defects in TR null mice makes its role in the pathogenesis of $\mathrm{CDH}$ less likely. Even though nitrofen and thyroid hormones have similar structures, a clear relation between the thyroid signaling pathway and lung or diaphragm defects has not been demonstrated so far.

Similar to the surgical CDH models, the nitrofen model has been used to study vascular defects in $\mathrm{CDH}$ [99]. However, a detailed discussion of vascular abnormalities associated with $\mathrm{CDH}$ is beyond the scope of this review.

The nitrofen model is based on the administration of the herbicide before the onset of lung and diaphragm formation. Although this model appears to be the best model available since the timing of the developmental insult is similar to that in humans, a large disadvantage is that the significance of the potential teratogenic effects of nitrofen in rodents has never been demonstrated in humans. Although increasing evidence of the etiology of $\mathrm{CDH}$ points towards a disturbance in the retinoid signaling and/or thyroid signaling pathways, the nitrofen model has not resolved the pathogenesis of $\mathrm{CDH}$ and the associated $\mathrm{PH}$.

\section{Genetic Models}

Since the first knockout mice were produced at the end of the eighties, they have been widely employed by molecular biologists to investigate the function of the gene that is made inoperable. In this way, several expected and unexpected genes have been linked to $\mathrm{CDH}$.

\section{Wilm's Tumor 1 (wt1)}

The original paper describing the phenotype of Wilm's tumor 1 (wt1) null mutant mice focused on the role of this tumor-suppressor gene in urogenital development [100]. In the same paper, the authors briefly describe the incomplete formation of the diaphragm in the mutants resulting in the herniation of the lungs into the abdominal cavity, whereas in human $\mathrm{CDH}$, abdominal contents normally herniate into the thorax. However, in a recent publication, Clugston et al. [101] describe a more classical picture of abdominal contents herniating into the thorax in a comparative study on diaphragm development in three animal models for $\mathrm{CDH}$ including wt1 null mutant mice. In addition, the authors observe a 'real' posterolateral (Bochdalek) hernia based on the malformation of the pleuroperitoneal folds as opposed to different diaphragmatic defects observed in other knockout mice. An accurate indication of the incidence of $\mathrm{CDH}$ could not be calculated because of the small numbers of fetuses investigated. Despite the 'true' Bochdalek phenotype of the wt1 null mutant mice, a translation to the human situation of $\mathrm{CDH}$ has not been made. Besides a few reports of mutations of WT1 in human case reports on syndromic $\mathrm{CDH}$ such as WAGR and Denysh Drash, no relationship between the presence of the WT1 mutation and isolated $\mathrm{CDH}$ was found [102-105]. In a Swedish series of 27 children with isolated $\mathrm{CDH}$ no WT1 gene mutations could be detected [106].

\section{Sonic Hedgehog (Shh) and Gli2/Gli3}

Sonic Hedgehog (Shh) and Gli2 and Gli3 are members of a highly conserved morphogenetic family known as the Shh-signaling pathway [107]. In the original publications on the functions of Shh and Gli2 and Gli3, no mention was made on the diaphragmatic defects some of the null mutant mice displayed. These papers focused on the foregut anomalies such as abnormal branching morphogenesis of the lungs, tracheal-esophageal fistula and esophageal atresia, respectively [108-110]. In Shh null mutants, there is a failure of tracheo-esophageal separation and, in addition, the lungs have undergone less branching morphogenesis, making them hypoplastic $[108,110]$. Interestingly, Shh expression is decreased in human hypoplastic lungs of $\mathrm{CDH}$ patients [111].

Studies from Gli2 and Gli3 double-knockout mice demonstrated a similar phenotype of foregut abnormalities, but a more severe phenotype of disturbed branching morphogenesis. Gli2 ${ }^{-/-}$mice have only one lobe on the right side (instead of four) indicating that lungs are formed, but primary branching is affected. In Gli $2^{-/-}$ $\mathrm{Gli3}^{-/-}$mice, no lungs are formed at all. In $\mathrm{Gli2}^{-/-} / \mathrm{Gli3}^{+/-}$ mice there is ectopic branching and fusion of lung lobes [109]. However, none of the first studies described a CDH in these mice. In a more recent publication, the same group demonstrated that the single null mutant mice for both Gli2 and Gli3 as well as the double mutant $\mathrm{Gli2}^{-/-}$ $\mathrm{Gli3}^{+/-}$mice have diaphragmatic defects [112]. No description of the type of hernia was given for either Shh or Gli null mutant mice. No relationship between a mutation in GLI genes and CDH has been demonstrated in humans so far. 
Slit3

Slit3 belongs to the family of Slit guiding proteins that are highly conserved throughout evolution. Especially Slit 1 and Slit 2 have been investigated for their role in axon guidance and cell migration [reviewed in 113]. Approximately $70 \%$ of Slit3 null mutant mice have a CDH [114, 115]. In contrast to other animal models for $\mathrm{CDH}$, most of these mice do not die after birth. The mice display a defect in the central tendon of the diaphragm, which fails to detach from the liver on the right side, thereby making it a good model of the human central (septum transversum) type of hernia. The origin of the defect lies in a defective connective tissue formation in the central septum transversum. The innervation of the phrenic nerve to the diaphragm was found to be normal in the knockout mice. No primary lung phenotype was observed in the mice. However, mice with end-stage $\mathrm{CDH}$ were short of breath due to atelectasis and intrapulmonary hemorrhage. Altogether, these data suggest that Slit 3 might play a role in a small subgroup of $\mathrm{CDH}$ cases. Recently, a case report of a newborn with $\mathrm{CDH}$ with a hernia sac attached to the liver was published [116]. The left side of the liver formed a part of the sac of the $\mathrm{CDH}$. Liver tissue including vessels was seen in the sac, as seen in Slit3 ${ }^{-/-}$mice [115]. This is the first time that presence of hepatocytes within the sac itself was observed in a patient with $\mathrm{CDH}$.

\section{Fog2 (Friend of GATA)}

Employing an elegant approach of high-throughput mutagenesis analysis using the chemical mutagen $\mathrm{N}$ ethyl-N-nitrosourea, Ackerman et al. [117] identified a mouse line with respiratory failure at birth. This phenotype was based on $\mathrm{PH}$, disturbed heart development and a diaphragmatic defect and could be linked to a mutation in the gene Fog2 (Friend of GATA). In contrast to the other models, these mice displayed severe $\mathrm{PH}$ in the absence of a hole in the diaphragm. Instead, a posterolateral muscularization defect was observed. As such, this phenotype correlates better to the human situation of $\mathrm{CDH}$ with regard to the existence of $\mathrm{PH}$. Interestingly, the authors demonstrated that $\mathrm{PH}$ occurs independently of deficient diaphragm development. This is a situation that can also be observed in unilateral agenesis of the lung with an intact diaphragm. Others and we have demonstrated that the same holds true for lung development in the nitrofen model of $\mathrm{CDH}[48,118,119]$. However, a clear relationship between disturbed lung development and diaphragmatic development has not been shown. It is more likely that both lungs and diaphragm are disturbed in their development separately.

Animal Models in $\mathrm{CDH}$
Subsequently, the authors searched for FOG2 mutations in a series of 30 autopsy specimens of $\mathrm{CDH}$ patients and found a nonsense mutation in a female patient with severe bilateral $\mathrm{PH}$ and a posterior diaphragmatic eventration on the left side. The authors suggested that this was the first reported gene mutation in a patient with $\mathrm{CDH}$ and PH. More recently, Bleyl et al. [120] reported novel FOG2 sequence variants in 2 isolated $\mathrm{CDH}$ patients, but could not identify them as mutations.

\section{Gata4 and Gata6}

Fog2 can interact with many different transcription factors such as the Gata zinc finger transcription factors Gata4 and Gata6. Null mutant mice for both Gata4 and Gata6 die early in embryonic development because of the essential roles of these factors in ventral morphogenesis (including heart development) and differentiation of visceral endoderm, respectively [121-123]. Therefore, these models could not be used to evaluate their roles in lung or diaphragm development that occur later in gestation. However, others and we demonstrated that Gata6 is essential for normal branching morphogenesis of the lung and late epithelial cell differentiation using a chimeric mouse mutagenesis approach [124-126]. So far Gata6 has not been implicated in diaphragm development. A role for Gata4 in lung or diaphragm development was recently observed by Jay et al. [127]. They noticed disturbed heart, lung and diaphragm development in approximately $70 \%$ of heterozygous Gata 4 knockout mice that were generated in a different genetic background [127]. The mutation resulted in a mortality of up to $40 \%$. The defect in the diaphragms consisted of a ventral hernia covered with a sac that was not attached to the liver, but allowed abdominal viscera to protrude. The incidence of $\mathrm{CDH}$ was approximately $30 \%$. Pulmonary development in the mutant mice was not very disturbed although the authors describe some airway dilatation and altered expression of certain genes in the most affected mice. In addition, another study recently demonstrated that Gata4 is important for normal pulmonary lobar development [128]. Interestingly, a microdeletion on human chromosome 8p23.1 that includes the GATA4 gene, has been linked to isolated human cases of $\mathrm{CDH}$ especially in combination with cardiac anomalies [129-132].

\section{COUP-TFII}

Another transcription factor that is a binding partner of Fog2 is COUP-TFII, which belongs to a nuclear steroid/ thyroid/retinoid hormone receptor superfamily and has been shown to be essential for embryonic mouse develop- 
ment [133]. Mice lacking COUP-TFII show defects in cardiovascular development and die around day 10.5 of gestation. Conditional mutagenesis of COUP-TFII in mice using the Cre-lox conditional knockout system to ablate COUP-TFII function in the mesenchyme only resulted in a Bochdalek-type diaphragmatic defect on the left side [134]. However, the authors did not find a deficient lung phenotype in these mice, although this might be due to the tissue-specific ablation of the gene in the mesenchyme. In line with the latter idea, the authors state that COUP-TFII expression is markedly decreased in the structures contributing to the developing diaphragm such as the pleuroperitoneal folds, but the expression was only slightly reduced in the developing lung. These results are even more interesting in the light of the location of COUP-TFII on human chromosome 15q26. Our group has identified this region as a potential candidate region for human patients with isolated $\mathrm{CDH}[135,136]$. However, following an evaluation of over 130 cases of isolated $\mathrm{CDH}$ from different hospitals, no mutations in the coding regions of COUP-TFII have yet been identified.

\section{Platelet-Derived Growth Factor Receptor- $\alpha$}

Very recently, the platelet-derived growth factor receptor- $\alpha$ (PDGFR $\alpha$ ) gene has been identified as an important factor in the formation of the diaphragm and lung development [120]. This gene is known for its role in tumorigenesis of gastrointestinal and neural tumors [137-140]. In pdgfr $\alpha$ null mice, Bleyl et al. [120] observed $\mathrm{PH}$ and a range of diaphragmatic defects including posterolateral diaphragmatic hernias. This and the other phenotypical characteristics observed are similar to the human Fryns syndrome (nonisolated CDH) [141]. Hence PDGFR $\alpha$ might be a candidate gene for nonisolated $\mathrm{CDH}$. Moreover, in one patient with nonisolated $\mathrm{CDH}$ a novel sequence variant of PDGFR $\alpha$ was identified. The authors did not prove the variant to be a mutation [120].

\section{Retinoid Signaling Pathway in Knockout Mice}

Increasing evidence from data obtained with the nitrofen model and knockout mice points towards perturbations in the retinoid signaling pathway. For example, COUP-TFII has been shown to be a downstream target of retinoid signaling [reviewed in 142]. In addition, different Gata transcription factors have been demonstrated to interact with RARs [143]. Therefore, we also want to review the role of members of the retinoid signaling pathway in knockout mice. The first evidence from knockout mice that RA is involved in the pathogenesis of $\mathrm{CDH}$ came from RAR double-knockout mice, as described earlier.
Single RAR null mutant mice did not show the expected anomalies that were observed in the vitamin-A-deficient rats, indicating that the different types of receptors are highly redundant [144-147]. However, when the function of multiple receptors was abolished, multiple congenital abnormalities were observed including right-sided $\mathrm{CDH}$ in RAR $\alpha \beta 2$ and left-sided CDH in RAR $\alpha \beta 2^{+/-}$. In addition, these mice displayed severe PH [57]. Despite the convincing data from animal studies, the results in humans have been limited. Until now the only described mutations in $\mathrm{CDH}$ patients related to the RA pathway are in STRA6 and CRABP1 on chromosome 15 [59-61, 7476]. A study evaluating the RA status of $\mathrm{CDH}$ cases, their mothers and age-matched controls is currently under way.

Despite the ample evidence that certain genes are involved in the pathogenesis of different types of $\mathrm{CDH}$, only a mutation in FOG2 has so far been demonstrated in a single patient with nonsyndromic $\mathrm{CDH}$. This might be due to several factors. First, as described for the Gata4 gene, the genetic background of the species carrying the mutation is of importance for the phenotype that is related to the mutation. The diaphragmatic defect was only observed in heterozygous $\mathrm{C} 57 \mathrm{Bl} / 6$ Gata4 mutant mice. This is also true for the rodent model based on the teratogenic effects of nitrofen. When nitrofen is administered to Sprague-Dawley rats, the percentage of the offspring having $\mathrm{CDH}$ is higher than following administration to Wistar rats. The same phenomenon has been observed in different mouse strains. Second, the pathogenesis of CDH might be explained by the necessity of multiple developmental insults to happen during development of the diaphragm and the lung. We and others demonstrated this scenario for $\mathrm{PH}$ in the nitrofen model for $\mathrm{CDH}$ [48]. We named this the dual-hit hypothesis. Finally, the observed phenotype in $\mathrm{CDH}$ is so variable that it is potentially not due to a single gene mutation, but the result of multiple gene mutations. Different genes involved in different signaling pathways that have been shown to be important for normal embryonic development might be involved. In addition, as has been suggested for the nitrofen model, there may be a disturbed interaction of certain genes with environmental factors.

\section{Concluding Remarks}

Surgical models have been of great importance for validating new interventions in $\mathrm{CDH}$. Many new approaches used today in $\mathrm{CDH}$ patients, as for example FETO, 
were first optimized in surgical animal models. However, these models are less suitable than either nitrofen or genetic models for elucidating the pathogenesis of $\mathrm{CDH}$, since the diaphragmatic defect is created rather late in fetal development. A combination of two models might further improve our understanding of $\mathrm{CDH}$-associated PH [148]. Nitrofen has never been demonstrated to cause $\mathrm{CDH}$ in humans, despite its massive use as a herbicide. Nevertheless, the nitrofen rodent model has great similarities with human $\mathrm{CDH}$. The most plausible pathogenetic explanation for $\mathrm{CDH}$ and its associated anomalies is a general genetic defect that causes cardiovascular, lung and diaphragm defects. However, this particular genetic defect has not been found, although some mouse models resemble human $\mathrm{CDH}$. A new approach to discover changes in the genetics of $\mathrm{CDH}$ in human cases is the genome-wide array. Genome-wide arrays are useful to compare the genetic changes between $\mathrm{CDH}$ patients and to search for the existence of CDH-related genes. Up to now, such an approach has only been attempted in nonisolated (syndromic) human cases, mainly for Fryns syndrome $[136,149,150]$.

Although none of the animal models perfectly mimic human $\mathrm{CDH}$ and its associated anomalies, they all have shed light on the underlying pathogenesis of the disease.
Increasing evidence from studies in both human $\mathrm{CDH}$ and animal models of CDH (nitrofen and knockout mice) suggest that a disturbance in the retinoid signaling pathway might be responsible for the anomaly. However, not all findings can solely be explained by disturbances in this pathway. Based on the spectrum of defects in heart, lungs and diaphragm, it is likely that there is a general defect in mesenchymal signaling in all organs involved in $\mathrm{CDH}$. More research is warranted to improve our understanding of normal and abnormal diaphragm and lung development in relation to $\mathrm{CDH}$. Eventually, such investigations will help in the design of new treatment modalities to improve the natural course or even to prevent this anomaly.

\section{Acknowledgements}

This work was supported by the Canadian Institute of Health Research (MOP-77751), Ottawa, Canada; an Erasmus MC fellowship, Rotterdam, The Netherlands; Foundation 'Sophia Kinderziekenhuis', Rotterdam, The Netherlands; Michaël-Van Vloten Foundation, Rotterdam, The Netherlands; 'De Drie Lichten' Foundation, Leiden, The Netherlands and Trustfonds, Rotterdam, The Netherlands.

\section{References}

1 Langham MR Jr, Kays DW, Ledbetter DJ, Frentzen B, Sanford LL, Richards DS: Congenital diaphragmatic hernia. Epidemiology and outcome. Clin Perinatol 1996;23:671688.

2 Kays DW: Congenital diaphragmatic hernia and neonatal lung lesions. Surg Clin North Am 2006;86:329-352, IX.

- 3 Rottier R, Tibboel D: Fetal lung and diaphragm development in congenital diaphragmatic hernia. Semin Perinatol 2005; 29:86-93.

4 Grosfeld JL, O’Neill JA, Fonkalsrud EW, Coran AG: Pediatric Surgery, ed 6. Philadelphia, Mosby-Elsevier, 2006, pp 931-954.

5 Logan JW, Rice HE, Goldberg RN, Cotten CM: Congenital diaphragmatic hernia: a systematic review and summary of best-evidence practice strategies. J Perinatol 2007;27: 535-549.

6 Holder AM, Klaassens M, Tibboel D, de Klein A, Lee B, Scott DA: Genetic factors in congenital diaphragmatic hernia. Am J Hum Genet 2007;80:825-845.
Delorimier AA, Tierney DF, Parker HR: Hypoplastic lungs in fetal lambs with surgically produced congenital diaphragmatic hernia. Surgery 1967;62:12-17.

-8 Lipsett J, Cool JC, Runciman SI, Ford WD, Kennedy JD, Martin AJ: Effect of antenatal tracheal occlusion on lung development in the sheep model of congenital diaphragmatic hernia: a morphometric analysis of pulmonary structure and maturity. Pediatr Pulmonol 1998;25:257-269.

-9 Flemmer AW, Jani JC, Bergmann F, Muensterer OJ, Gallot D, Hajek K, Sugawara J, Till H, Deprest JA: Lung tissue mechanics predict lung hypoplasia in a rabbit model for congenital diaphragmatic hernia. Pediatr Pulmonol 2007;42:505-512.

$10 \mathrm{Wu}$ J, Yamamoto H, Gratacos E, Ge X, Verbeken E, Sueishi K, Hashimoto S, Vanamo K, Lerut T, Deprest J: Lung development following diaphragmatic hernia in the fetal rabbit. Hum Reprod 2000;15:2483-2488.
11 Davey MG, Danzer E, Schwarz U, Adzick NS, Flake AW, Hedrick HL: Prenatal glucocorticoids and exogenous surfactant therapy improve respiratory function in lambs with severe diaphragmatic hernia following fetal tracheal occlusion. Pediatr Res 2006;60:131135.

12 Roubliova XI, Van der Biest AM, Vaast P, Lu H, Jani JC, Lewi PJ, Verbeken EK, Tibboel D, Deprest JA: Effect of maternal administration of betamethasone on peripheral arterial development in fetal rabbit lungs. Neonatology 2008;93:64-72.

13 Ford WD, Cool J, Derham R: Intrathoracic silo for the potential antenatal repair of diaphragmatic herniae with liver in the chest. Fetal Diagn Ther 1992;7:75-81.

14 Harrison MR, Adzick NS, Longaker MT, Goldberg JD, Rosen MA, Filly RA, Evans MI, Golbus MS: Successful repair in utero of a fetal diaphragmatic hernia after removal of herniated viscera from the left thorax. N Engl J Med 1990;322:1582-1584. 
15 Lipsett J, Cool JC, Runciman SC, Ford WD, Parsons DW, Kennedy JD, Martin AJ: Effect of immediate versus slow intrauterine reduction of congenital diaphragmatic hernia on lung development in the sheep: a morphometric analysis of term pulmonary structure and maturity. Pediatr Pulmonol 2000;30: 228-240.

- 16 De Paepe ME, Johnson BD, Papadakis K, Luks FI: Lung growth response after tracheal occlusion in fetal rabbits is gestational agedependent. Am J Respir Cell Mol Biol 1999; 21:65-76.

- 17 DiFiore JW, Fauza DO, Slavin R, Peters CA, Fackler JC, Wilson JM: Experimental fetal tracheal ligation reverses the structural and physiological effects of pulmonary hypoplasia in congenital diaphragmatic hernia. J Pediatr Surg 1994;29:248-256; discussion 256257.

18 Wilson JM, DiFiore JW, Peters CA: Experimental fetal tracheal ligation prevents the pulmonary hypoplasia associated with fetal nephrectomy: possible application for congenital diaphragmatic hernia. J Pediatr Surg 1993;28:1433-1439; discussion 1439-1440.

19 Wigglesworth JS, Desai R, Hislop AA: Fetal lung growth in congenital laryngeal atresia. Pediatr Pathol 1987;7:515-525.

-20 Harrison MR, Adzick NS, Flake AW, VanderWall KJ, Bealer JF, Howell LJ, Farrell JA, Filly RA, Rosen MA, Sola A, Goldberg JD: Correction of congenital diaphragmatic hernia in utero. VIII. Response of the hypoplastic lung to tracheal occlusion. J Pediatr Surg 1996;31:1339-1348.

-21 Harrison MR, Mychaliska GB, Albanese CT, Jennings RW, Farrell JA, Hawgood S, Sandberg P, Levine AH, Lobo E, Filly RA: Correction of congenital diaphragmatic hernia in utero. IX. Fetuses with poor prognosis (liver herniation and low lung-to-head ratio) can be saved by fetoscopic temporary tracheal occlusion. J Pediatr Surg 1998;33:1017-1022; discussion 1022-1023.

-22 Harrison MR, Sydorak RM, Farrell JA, Kitterman JA, Filly RA, Albanese CT: Fetoscopic temporary tracheal occlusion for congenital diaphragmatic hernia: prelude to a randomized, controlled trial. J Pediatr Surg 2003;38:1012-1020.

-23 Bratu I, Flageole H, Laberge JM, Kovacs L, Faucher D, Piedboeuf B: Lung function in lambs with diaphragmatic hernia after reversible fetal tracheal occlusion. J Pediatr Surg 2004;39:1524-1531.

-24 Deprest JA, Evrard VA, Van Ballaer PP, Verbeken E, Vandenberghe K, Lerut TE, Flageole $\mathrm{H}$ : Tracheoscopic endoluminal plugging using an inflatable device in the fetal lamb model. Eur J Obstet Gynecol Reprod Biol 1998;81:165-169.

-25 Skarsgard ED, Meuli M, VanderWall KJ, Bealer JF, Adzick NS, Harrison MR: Fetal endoscopic tracheal occlusion ('fetendo-plug') for congenital diaphragmatic hernia. J Pediatr Surg 1996;31:1335-1338.
$26 \mathrm{Wu}$ J, Ge X, Verbeken EK, Gratacos E, Yesildaglar N, Deprest JA: Pulmonary effects of in utero tracheal occlusion are dependent on gestational age in a rabbit model of diaphragmatic hernia. J Pediatr Surg 2002;37:11-17.

27 Harrison MR, Keller RL, Hawgood SB, Kitterman JA, Sandberg PL, Farmer DL, Lee H, Filly RA, Farrell JA, Albanese CT: A randomized trial of fetal endoscopic tracheal occlusion for severe fetal congenital diaphragmatic hernia. N Engl J Med 2003;349: 1916-1924.

28 Roubliova XI, Verbeken EK, Wu J, Vaast P, Jani J, Deprest JA: Effect of tracheal occlusion on peripheric pulmonary vessel muscularization in a fetal rabbit model for congenital diaphragmatic hernia. Am J Obstet Gynecol 2004;191:830-836.

29 Deprest J, Gratacos E, Nicolaides KH: Fetoscopic tracheal occlusion (FETO) for severe congenital diaphragmatic hernia: evolution of a technique and preliminary results. Ultrasound Obstet Gynecol 2004;24:121-126.

30 Lipshutz GS, Albanese CT, Feldstein VA, Jennings RW, Housley HT, Beech R, Farrell JA, Harrison MR: Prospective analysis of lung-to-head ratio predicts survival for patients with prenatally diagnosed congenital diaphragmatic hernia. J Pediatr Surg 1997; 32:1634-1636

31 Deprest J, Jani J, Cannie M, Debeer A, Vandevelde M, Done E, Gratacos E, Nicolaides K: Prenatal intervention for isolated congenital diaphragmatic hernia. Curr Opin Obstet Gynecol 2006;18:355-367.

32 Deprest J, Jani J, Gratacos E, Vandecruys $\mathrm{H}$ Naulaers G, Delgado J, Greenough A, Nicolaides K: Fetal intervention for congenital diaphragmatic hernia: the European experience. Semin Perinatol 2005;29:94-103.

33 Gucciardo L, Deprest J, Done E, Van Mieghem T, Van de Velde M, Gratacos E, Jani J, Peralta F, Nicolaides K: Prediction of outcome in isolated congenital diaphragmatic hernia and its consequences for fetal therapy. Best Pract Res Clin Obstet Gynaecol 2008;22:123-138.

34 Jani J, Gratacos E, Greenough A, Piero JL, Benachi A, Harrison M, Nicolaides K, Deprest J: Percutaneous fetal endoscopic tracheal occlusion (FETO) for severe left-sided congenital diaphragmatic hernia. Clin $\mathrm{Ob}$ stet Gynecol 2005;48:910-922.

35 Jani JC, Nicolaides KH, Gratacos E, Vandecruys H, Deprest JA: Fetal lung-to-head ratio in the prediction of survival in severe leftsided diaphragmatic hernia treated by fetal endoscopic tracheal occlusion (FETO). Am J Obstet Gynecol 2006;195:1646-1650.
-36 Peralta CF, Jani JC, Van Schoubroeck D, Nicolaides KH, Deprest JA: Fetal lung volume after endoscopic tracheal occlusion in the prediction of postnatal outcome. Am J Obstet Gynecol 2008;198:60e61-60e65.

37 Done E, Gucciardo L, Van Mieghem T, Jani J, Cannie M, Van Schoubroeck D, Devlieger R, Catte LD, Klaritsch P, Mayer S, Beck V, Debeer A, Gratacos E, Nicolaides K, Deprest $\mathrm{J}$ : Prenatal diagnosis, prediction of outcome and in utero therapy of isolated congenital diaphragmatic hernia. Prenat Diagn 2008; 28:581-591.

- 38 Bratu I, Flageole H, Laberge JM, Chen MF, Piedboeuf B: Pulmonary structural maturation and pulmonary artery remodeling after reversible fetal ovine tracheal occlusion in diaphragmatic hernia. J Pediatr Surg 2001; 36:739-744

39 Luks FI, Wild YK, Piasecki GJ, De Paepe ME: Short-term tracheal occlusion corrects pulmonary vascular anomalies in the fetal lamb with diaphragmatic hernia. Surgery 2000; 128:266-272.

40 Sylvester KG, Rasanen J, Kitano Y, Flake AW, Crombleholme TM, Adzick NS: Tracheal occlusion reverses the high impedance to flow in the fetal pulmonary circulation and normalizes its physiological response to oxygen at full term. J Pediatr Surg 1998;33:10711074; discussion 1074-1075.

41 de Buys Roessingh AS, de Lagausie P, Barbet JP, Mercier JC, Aigrain Y, Dinh-Xuan AT: Role of ATP-dependent potassium channels in pulmonary vascular tone of fetal lambs with congenital diaphragmatic hernia. Pediatr Res 2006;60:537-542.

42 de Buys Roessingh AS, de Lagausie P, Ibrahima T, Duong-Quy S, Schneider JC, Huang XL, Mercier JC, Aigrain Y, Boulanger C, Dinh-Xuan AT: Neuronal nitric oxide synthase does not contribute to the modulation of pulmonary vascular tone in fetal lambs with congenital diaphragmatic hernia (NNOS in CDH lambs). Pediatr Pulmonol 2008;43:313-321.

43 Roubliova X, Verbeken E, Wu J, Yamamoto $\mathrm{H}$, Lerut T, Tibboel D, Deprest J: Pulmonary vascular morphology in a fetal rabbit model for congenital diaphragmatic hernia. J Pediatr Surg 2004;39:1066-1072.

44 Harrison MR, Jester JA, Ross NA: Correction of congenital diaphragmatic hernia in utero. I. The model: intrathoracic balloon produces fatal pulmonary hypoplasia. Surgery 1980;88:174-182.

45 Ohi R, Suzuki H, Kato T, Kasai M: Development of the lung in fetal rabbits with experimental diaphragmatic hernia. J Pediatr Surg 1976;11:955-959.

-46 Bratu I, Flageole H, Laberge JM, Possmayer F, Harbottle R, Kay S, Khalife S, Piedboeuf B: Surfactant levels after reversible tracheal occlusion and prenatal steroids in experimental diaphragmatic hernia. J Pediatr Surg 2001;36:122-127. 
\47 Tannuri U, Rodrigues CJ, Maksoud-Filho JG, Santos MM, Tannuri AC, Rodrigues AJ Jr: The effects of prenatal intra-amniotic surfactant or dexamethasone administration on lung development are comparable to changes induced by tracheal ligation in an animal model of congenital diaphragmatic hernia: studies of lung glycogen content, elastic fiber density, and collagen content. J Pediatr Surg 1998;33:1776-1783.

-48 Keijzer R, Liu J, Deimling J, Tibboel D, Post M: Dual-hit hypothesis explains pulmonary hypoplasia in the nitrofen model of congenital diaphragmatic hernia. Am J Pathol 2000; 156:1299-1306.

49 Costlow RD, Manson JM: The heart and diaphragm: target organs in the neonatal death induced by nitrofen (2,4-dichlorophenyl- $p$ nitrophenyl ether). Toxicology 1981;20:209227.

- 50 Ambrose AM, Larson PS, Borzelleca JF, Smith RB Jr, Hennigar GR Jr: Toxicologic studies on 2,4-dichlorophenyl-p-nitrophenyl ether. Toxicol Appl Pharmacol 1971;19: 263-275.

-51 Migliazza L, Otten C, Xia H, Rodriguez JI, Diez-Pardo JA, Tovar JA: Cardiovascular malformations in congenital diaphragmatic hernia: human and experimental studies. J Pediatr Surg 1999;34:1352-1358.

-52 Migliazza L, Xia H, Alvarez JI, Arnaiz A, Diez-Pardo JA, Alfonso LF, Tovar JA: Heart hypoplasia in experimental congenital diaphragmatic hernia. J Pediatr Surg 1999;34: 706-710; discussion 710-711.

-53 Migliazza L, Xia H, Diez-Pardo JA, Tovar JA: Skeletal malformations associated with congenital diaphragmatic hernia: experimental and human studies. J Pediatr Surg 1999;34: 1624-1629.

-54 Tenbrinck R, Tibboel D, Gaillard JL, Kluth D, Bos AP, Lachmann B, Molenaar JC: Experimentally induced congenital diaphragmatic hernia in rats. J Pediatr Surg 1990;25: 426-429.

55 Andersen DH: Incidence of congenital diaphragmatic hernia in the young of rats bred on a diet deficient in vitamin A. Am J Dis Child 1941;62:888-889.

-56 Wilson JG, Roth CB, Warkany J: An analysis of the syndrome of malformations induced by maternal vitamin A deficiency. Effects of restoration of vitamin $\mathrm{A}$ at various times during gestation. Am J Anat 1953;92:189217.

57 Mendelsohn C, Lohnes D, Decimo D, Lufkin T, LeMeur M, Chambon P, Mark M: Function of the RA receptors (RARs) during development (II). Multiple abnormalities at various stages of organogenesis in RAR double mutants. Development 1994;120:27492771.

58 Major D, Cadenas M, Fournier L, Leclerc S, Lefebvre M, Cloutier R: Retinol status of newborn infants with congenital diaphragmatic hernia. Pediatr Surg Int 1998;13:547549.
59 Enns GM, Cox VA, Goldstein RB, Gibbs DL, Harrison MR, Golabi M: Congenital diaphragmatic defects and associated syndromes, malformations, and chromosome anomalies: a retrospective study of $60 \mathrm{pa}$ tients and literature review. Am J Med Genet 1998;79:215-225.

60 Biggio JR Jr, Descartes MD, Carroll AJ, Holt RL: Congenital diaphragmatic hernia: is 15q26.1-26.2 a candidate locus? Am J Med Genet A 2004;126:183-185.

61 Greer JJ, Babiuk RP, Thebaud B: Etiology of congenital diaphragmatic hernia: the retinoid hypothesis. Pediatr Res 2003;53:726730.

62 Iritani I: Experimental study on embryogenesis of congenital diaphragmatic hernia. Anat Embryol (Berl) 1984;169:133-139.

63 Kluth D, Tenbrinck R, von Ekesparre M, Kangah R, Reich P, Brandsma A, Tibboel D, Lambrecht W: The natural history of congenital diaphragmatic hernia and pulmonary hypoplasia in the embryo. J Pediatr Surg 1993;28:456-462; discussion 462-463.

64 Montedonico S, Nakazawa N, Puri P: Retinoic acid rescues lung hypoplasia in nitrofen-induced hypoplastic foetal rat lung explants. Pediatr Surg Int 2006;22:2-8.

65 Thebaud B, Barlier-Mur AM, Chailley-Heu B, Henrion-Caude A, Tibboel D, Dinh-Xuan AT, Bourbon JR: Restoring effects of vitamin A on surfactant synthesis in nitrofen-induced congenital diaphragmatic hernia in rats. Am J Respir Crit Care Med 2001;164: 1083-1089.

66 Thebaud B, Tibboel D, Rambaud C, Mercier JC, Bourbon JR, Dinh-Xuan AT, Archer SL: Vitamin A decreases the incidence and severity of nitrofen-induced congenital diaphragmatic hernia in rats. Am J Physiol 1999;277:L423-L429.

67 Babiuk RP, Thebaud B, Greer JJ: Reductions in the incidence of nitrofen-induced diaphragmatic hernia by vitamin A and retinoic acid. Am J Physiol Lung Cell Mol Physiol 2004;286:L970-L973.

68 Duester G: Families of retinoid dehydrogenases regulating vitamin A function: production of visual pigment and retinoic acid. Eur J Biochem 2000;267:4315-4324.

69 Duester G: Involvement of alcohol dehydrogenase, short-chain dehydrogenase/reductase, aldehyde dehydrogenase, and cytochrome p450 in the control of retinoid signaling by activation of retinoic acid synthesis. Biochemistry 1996;35:12221-12227.

70 Hind M, Corcoran J, Maden M: Alveolar proliferation, retinoid synthesizing enzymes, and endogenous retinoids in the postnatal mouse lung. Different roles for ALDH-1 and RALDH-2. Am J Respir Cell Mol Biol 2002;26:67-73.

71 Mey J, Babiuk RP, Clugston R, Zhang W, Greer JJ: Retinal dehydrogenase-2 is inhibited by compounds that induce congenital diaphragmatic hernias in rodents. Am J Pathol 2003;162:673-679.
72 Noble BR, Babiuk RP, Clugston RD, Underhill TM, Sun H, Kawaguchi R, Walfish PG, Blomhoff R, Gundersen TE, Greer JJ: Mechanisms of action of the congenital diaphragmatic hernia-inducing teratogen nitrofen. Am J Physiol Lung Cell Mol Physiol 2007; 293:L1079-L1087.

73 Nakazawa N, Montedonico S, Takayasu H, Paradisi F, Puri P: Disturbance of retinol transportation causes nitrofen-induced hypoplastic lung. J Pediatr Surg 2007;42:345349.

74 Golzio C, Martinovic-Bouriel J, Thomas S, Mougou-Zrelli S, Grattagliano-Bessières B, Bonnière $\mathrm{M}$, Delahaye $S$, Munnich A, EnchaRazavi F, Lyonnet S, Vekemans M, Attie-Bitach T, Etchevers HC: Matthew-Wood syndrome is caused by truncating mutations in the retinol-binding protein receptor gene STRA6. Am J Hum Genet 2007;80:11791187.

75 Kawaguchi R, Yu J, Honda J, Hu J, Whitelegge J, Ping P, Wiita P, Bok D, Sun H: A membrane receptor for retinol binding protein mediates cellular uptake of vitamin A. Science 2007;315:820-825.

76 Pasutto F, Sticht H, Hammersen G, Gillessen-Kaesbach G, Fitzpatrick DR, Nurnberg G, Brasch F, Schirmer-Zimmermann H, Tolmie JL, Chitayat D, Houge G, Fernandez-Martinez L, Keating S, Mortier G, Hennekam RC, von der Wense A, Slavotinek A, Meinecke P, Bitoun P, Becker C, Nurnberg P, Reis A, Rauch A: Mutations in STRA6 cause a broad spectrum of malformations including anophthalmia, congenital heart defects, diaphragmatic hernia, alveolar capillary dysplasia, lung hypoplasia, and mental retardation. Am J Hum Genet 2007;80:550-560.

-77 Ross AC: Retinoid production and catabolism: role of diet in regulating retinol esterification and retinoic acid oxidation. J Nutr 2003;133:291S-296S

78 Reijntjes S, Blentic A, Gale E, Maden M: The control of morphogen signalling: regulation of the synthesis and catabolism of retinoic acid in the developing embryo. Dev Biol 2005;285:224-237.

79 Chinoy MR, Chi X, Cilley RE: Down-regulation of regulatory proteins for differentiation and proliferation in murine fetal hypoplastic lungs: Altered mesenchymal-epithelial interactions. Pediatr Pulmonol 2001; 32:129-141.

80 Chen MH, MacGowan A, Ward S, Bavik C, Greer JJ: The activation of the retinoic acid response element is inhibited in an animal model of congenital diaphragmatic hernia. Biol Neonate 2003;83:157-161.

-81 Rajatapiti P, Keijzer R, Blommaart PE, Lamers WH, De Krijger RR, Visser TJ, Tibboel D, Rottier R: Spatial and temporal expression of glucocorticoid, retinoid, and thyroid hormone receptors is not altered in lungs of congenital diaphragmatic hernia. Pediatr Res 2006;60:693-698. 
82 Utiger RD: Thyroid hormone synthesis and physiology (2008). Retrieved June 27, 2008, at: http://www.utdol.com.

83 Gray LE Jr, Kavlock RJ: The effects of the herbicide 2,4-dichlorophenyl-p-nitrophenyl ether (NIT) on serum thyroid hormones in adult female mice. Toxicol Lett 1983;15:231235.

84 Manson JM, Brown T, Baldwin DM: Teratogenicity of nitrofen (2,4-dichloro-4'-nitrodiphenyl ether) and its effects on thyroid function in the rat. Toxicol Appl Pharmacol 1984; 73:323-335

- 85 Brandsma AE, Tibboel D, Vulto IM, de Vijlder JJ, Ten Have-Opbroek AA, Wiersinga WM: Inhibition of $\mathrm{T}_{3}$-receptor binding by nitrofen. Biochim Biophys Acta 1994;1201: 266-270.

86 Ayromlooi J, Berg PD, Valderrama E, Tobias MD: Midtrimester thyroidectomy in the ovine fetus. Pediatr Pharmacol (New York) 1983;3:15-28.

87 Holt J, Canavan JP, Goldspink DF: The influence of thyroid hormones on the growth of the lungs in perinatal rats. Int J Dev Biol 1993;37:467-472.

88 Keijzer R, Blommaart PJ, Labruyere WT, Vermeulen JL, Doulabi BZ, Bakker O, Tibboel D, Lamers WH: Expression of thyroid hormone receptors $\mathrm{A}$ and $\mathrm{B}$ in developing rat tissues; evidence for extensive posttranscriptional regulation. J Mol Endocrinol 2007;38: 523-535.

-89 Perez-Castillo A, Bernal J, Ferreiro B, Pans $\mathrm{T}$ : The early ontogenesis of thyroid hormone receptor in the rat fetus. Endocrinology 1985;117:2457-2461.

90 Bradley DJ, Towle HC, Young WS 3rd: Spatial and temporal expression of $\alpha$ - and $\beta$ thyroid hormone receptor MRNAs, including the $\beta_{2}$-subtype, in the developing mammalian nervous system. J Neurosci 1992;12:2288-2302.

-91 Morreale de Escobar G, Pastor R, Obregon MJ, Escobar del Rey F: Effects of maternal hypothyroidism on the weight and thyroid hormone content of rat embryonic tissues, before and after onset of fetal thyroid function. Endocrinology 1985;117:1890-1900.

-92 Obregon MJ, Mallol J, Pastor R, Morreale de Escobar G, Escobar del Rey F: L-thyroxine and 3,5,3'-triiodo-L-thyronine in rat embryos before onset of fetal thyroid function. Endocrinology 1984;114:305-307.

93 Vulsma T, Gons MH, de Vijlder JJ: Maternalfetal transfer of thyroxine in congenital hypothyroidism due to a total organification defect or thyroid agenesis. N Engl J Med 1989;321:13-16.

94 Manson JM: Mechanism of nitrofen teratogenesis. Environ Health Perspect 1986;70: 137-147.
95 Tovar JA, Qi B, Diez-Pardo JA, Alfonso LF, Arnaiz A, Alvarez FJ, Valls-i-Soler A, Morreale de Escobar G: Thyroid hormones in the pathogenesis of lung hypoplasia and immaturity induced in fetal rats by prenatal exposure to nitrofen. J Pediatr Surg 1997; 32:1295-1297.

-96 Teramoto H, Guarino N, Puri P: Altered gene level expression of thyroid hormone receptors alpha- 1 and beta- 1 in the lung of nitrofen-induced diaphragmatic hernia. J Pediatr Surg 2001;36:1675-1678.

97 Fraichard A, Chassande O, Plateroti M, Roux JP, Trouillas J, Dehay C, Legrand C, Gauthier K, Kedinger M, Malaval L, Rousset B, Samarut J: The T3R alpha gene encoding a thyroid hormone receptor is essential for post-natal development and thyroid hormone production. Embo J 1997;16: $4412-4420$

98 van Tuyl M, Blommaart PE, de Boer PA, Wert SE, Ruijter JM, Islam S, Schnitzer J, Ellison AR, Tibboel D, Moorman AF, Lamers WH: Prenatal exposure to thyroid hormone is necessary for normal postnatal development of murine heart and lungs. Dev Biol 2004;272:104-117.

99 Belik J, Davidge ST, Zhang W, Pan J, Greer JJ: Airway smooth muscle changes in the nitrofen-induced congenital diaphragmatic hernia rat model. Pediatr Res 2003;53: 737-743.

100 Kreidberg JA, Sariola H, Loring JM, Maeda M, Pelletier J, Housman D, Jaenisch R: WT1 is required for early kidney development. Cell 1993;74:679-691.

101 Clugston RD, Klattig J, Englert C, ClagettDame M, Martinovic J, Benachi A, Greer JJ: Teratogen-induced, dietary and genetic models of congenital diaphragmatic hernia share a common mechanism of pathogenesis. Am J Pathol 2006;169:1541-1549.

102 Cho HY, Lee BS, Kang CH, Kim WH, Ha IS, Cheong HI, Choi Y: Hydrothorax in a patient with Denys-Drash syndrome associated with a diaphragmatic defect. Pediatr Nephrol 2006;21:1909-1912.

103 Nordenskjold A, Friedman E, Anvret M WT1 mutations in patients with DenysDrash syndrome: a novel mutation in exon 8 and paternal allele origin. Hum Genet 1994;93:115-120.

104 Scott DA, Cooper ML, Stankiewicz P, Patel A, Potocki L, Cheung SW: Congenital diaphragmatic hernia in WAGR syndrome. Am J Med Genet A 2005;134:430-433.

105 Antonius T, van Bon B, Eggink A, van der Burgt I, Noordam K, van Heijst A: DenysDrash syndrome and congenital diaphragmatic hernia: another case with the $1097 \mathrm{G}$ $>\mathrm{A}(\arg 366 \mathrm{His})$ mutation. Am J Med Genet A 2008; 146:496-499.

-106 Nordenskjold A, Tapper-Persson M, Anvret M: No evidence of WT1 gene mutations in children with congenital diaphragmatic hernia. J Pediatr Surg 1996;31: 925-927.
107 Villavicencio EH, Walterhouse DO, Iannaccone PM: The sonic hedgehog-patchedgli pathway in human development and disease. Am J Hum Genet 2000;67:10471054.

108 Litingtung Y, Lei L, Westphal H, Chiang C: Sonic hedgehog is essential to foregut development. Nat Genet 1998;20:58-61.

109 Motoyama J, Liu J, Mo R, Ding Q, Post M, Hui CC: Essential function of Gli2 and Gli3 in the formation of lung, trachea and oesophagus. Nat Genet 1998;20:54-57.

110 Pepicelli CV, Lewis PM, McMahon AP: Sonic hedgehog regulates branching morphogenesis in the mammalian lung. Curr Biol 1998;8:1083-1086.

111 Unger S, Copland I, Tibboel D, Post M: Down-regulation of sonic hedgehog expression in pulmonary hypoplasia is associated with congenital diaphragmatic hernia. Am J Pathol 2003;162:547-555.

112 Kim PC, Mo R, Hui Cc C: Murine models of VACTERL syndrome: role of sonic hedgehog signaling pathway. J Pediatr Surg 2001;36:381-384

113 Brose K, Tessier-Lavigne M: Slit proteins: key regulators of axon guidance, axonal branching, and cell migration. Curr Opin Neurobiol 2000;10:95-102.

114 Liu J, Zhang L, Wang D, Shen H, Jiang M, Mei P, Hayden PS, Sedor JR, Hu H: Congenital diaphragmatic hernia, kidney agenesis and cardiac defects associated with Slit3-deficiency in mice. Mech Dev 2003; 120:1059-1070.

115 Yuan W, Rao Y, Babiuk RP, Greer JJ, Wu JY, Ornitz DM: A genetic model for a central (septum transversum) congenital diaphragmatic hernia in mice lacking Slit3. Proc Natl Acad Sci USA 2003;100:52175222.

-116 Sharma S, Jain R, Singh MK, Gupta DK: A case of congenital diaphragmatic hernia with a hernia sac attached to the liver: hints for an early embryological insult. J Pediatr Surg 2007;42:1761-1763.

117 Ackerman KG, Herron BJ, Vargas SO, Huang H, Tevosian SG, Kochilas L, Rao C, Pober BR, Babiuk RP, Epstein JA, Greer JJ, Beier DR: Fog2 is required for normal diaphragm and lung development in mice and humans. PLoS Genet 2005;1:58-65.

118 Guilbert TW, Gebb SA, Shannon JM: Lung hypoplasia in the nitrofen model of congenital diaphragmatic hernia occurs early in development. Am J Physiol Lung Cell Mol Physiol 2000;279:L1159-L1171.

119 Jesudason EC, Connell MG, Fernig DG, Lloyd DA, Losty PD: Early lung malformations in congenital diaphragmatic hernia. J Pediatr Surg 2000;35:124-127; discussion 128. 
120 Bleyl SB, Moshrefi A, Shaw GM, Saijoh Y, SchoenwolfGC, Pennacchio LA, Slavotinek AM: Candidate genes for congenital diaphragmatic hernia from animal models: sequencing of FOG2 and PDGFR $\alpha$ reveals rare variants in diaphragmatic hernia patients. Eur J Hum Genet 2007;15:950-958.

121 Kuo CT, Morrisey EE, Anandappa R, Sigrist K, Lu MM, Parmacek MS, Soudais C, Leiden JM: GATA4 transcription factor is required for ventral morphogenesis and heart tube formation. Genes Dev 1997;11: 1048-1060.

122 Molkentin JD, Lin Q, Duncan SA, Olson EN: Requirement of the transcription factor GATA4 for heart tube formation and ventral morphogenesis. Genes Dev 1997;11: 1061-1072.

-123 Morrisey EE, Tang Z, Sigrist K, Lu MM, Jiang F, Ip HS, Parmacek MS: GATA6 regulates HNF4 and is required for differentiation of visceral endoderm in the mouse embryo. Genes Dev 1998;12:3579-3590.

124 Kimura S: homeodomain transcription factor T/EBP/NKX2.1 in development and differentiation of the thyroid and lung (in Japanese). Seikagaku 2003;75:1493-1504.

125 Molkentin JD: The zinc finger-containing transcription factors GATA-4, -5 , and -6 . Ubiquitously expressed regulators of tissue-specific gene expression. J Biol Chem 2000;275:38949-38952.

126 Whitsett JA, Tichelaar JW: Forkhead transcription factor HFH-4 and respiratory epithelial cell differentiation. Am J Respir Cell Mol Biol 1999;21:153-154.

127 Jay PY, Bielinska M, Erlich JM, Mannisto S, $\mathrm{Pu}$ WT, Heikinheimo M, Wilson DB: Impaired mesenchymal cell function in GATA4 mutant mice leads to diaphragmatic hernias and primary lung defects. Dev Biol 2007;301:602-614

- 128 Ackerman KG, Wang J, Luo L, Fujiwara Y, Orkin SH, Beier DR: GATA4 is necessary for normal pulmonary lobar development. Am J Respir Cell Mol Biol 2007;36:391397.

-129 Barber JC, Maloney V, Hollox EJ, StukeSontheimer A, du Bois G, Daumiller E, Klein-Vogler U, Dufke A, Armour JA, Liehr $\mathrm{T}$ : Duplications and copy number variants of 8p23.1 are cytogenetically indistinguishable but distinct at the molecular level. Eur J Hum Genet 2005;13:1131-1136.

-130 Devriendt K, Matthijs G, Van Dael R, Gewillig M, Eyskens B, Hjalgrim H, Dolmer B, McGaughran J, Brondum-Nielsen K, Marynen P, Fryns JP, Vermeesch JR: Delineation of the critical deletion region for congenital heart defects, on chromosome 8p23.1. Am J Hum Genet 1999;64:11191126.
131 Faivre L, Morichon-Delvallez N, Viot G, Narcy F, Loison S, Mandelbrot L, Aubry MC, Raclin V, Edery P, Munnich A, Vekemans M: Prenatal diagnosis of an 8p23.1 deletion in a fetus with a diaphragmatic hernia and review of the literature. Prenat Diagn 1998;18:1055-1060.

132 Shimokawa O, Miyake N, Yoshimura T, Sosonkina N, Harada N, Mizuguchi T, Kondoh S, Kishino T, Ohta T, Remco V, Takashima T, Kinoshita A, Yoshiura K, Niikawa N, Matsumoto N: Molecular characterization of $\operatorname{del}(8)(\mathrm{p} 23.1 \mathrm{p} 23.1)$ in a case of congenital diaphragmatic hernia. Am J Med Genet A 2005;136:49-51

133 Pereira FA, Qiu Y, Zhou G, Tsai MJ, Tsai SY: The orphan nuclear receptor COUP-TFII is required for angiogenesis and heart development. Genes Dev 1999;13:1037-1049.

134 You LR, Takamoto N, Yu CT, Tanaka T, Kodama T, Demayo FJ, Tsai SY, Tsai MJ: Mouse lacking COUP-TFII as an animal model of Bochdalek-type congenital diaphragmatic hernia. Proc Natl Acad Sci USA 2005;102:16351-16356.

135 Klaassens M, van Dooren M, Eussen HJ, Douben H, den Dekker AT, Lee C, Donahoe PK, Galjaard RJ, Goemaere N, de Krijger RR, Wouters C, Wauters J, Oostra BA, Tibboel D, de Klein A: Congenital diaphragmatic hernia and chromosome 15q26: determination of a candidate region by use of fluorescent in situ hybridization and arraybased comparative genomic hybridization. Am J Hum Genet 2005;76:877-882.

-136 Scott DA, Klaassens M, Holder AM, Lally KP, Fernandes CJ, Galjaard RJ, Tibboel D, de Klein A, Lee B: Genome-wide oligonucleotide-based array comparative genome hybridization analysis of non-isolated congenital diaphragmatic hernia. Hum Mol Genet 2007; 16:424-430

137 Clarke ID, Dirks PB: A human brain tumor-derived PDGFR- $\alpha$ deletion mutant is transforming. Oncogene 2003;22:722-733.

138 Corless CL, Schroeder A, Griffith D, Town A, McGreevey L, Harrell P, Shiraga S, Bainbridge T, Morich J, Heinrich MC: PDGFR $\alpha$ mutations in gastrointestinal stromal tumors: frequency, spectrum and in vitro sensitivity to imatinib. J Clin Oncol 2005; 23:5357-5364.

139 Hirota S, Ohashi A, Nishida T, Isozaki K, Kinoshita K, Shinomura Y, Kitamura Y: Gain-of-function mutations of platelet-derived growth factor receptor $\alpha$ gene in gastrointestinal stromal tumors. Gastroenterology 2003;125:660-667.
140 Rand V, Huang J, Stockwell T, Ferriera S, Buzko O, Levy S, Busam D, Li K, Edwards JB, Eberhart C, Murphy KM, Tsiamouri A, Beeson K, Simpson AJ, Venter JC, Riggins GJ, Strausberg RL: Sequence survey of receptor tyrosine kinases reveals mutations in glioblastomas. Proc Natl Acad Sci USA 2005; 102:14344-14349.

141 Slavotinek AM: Fryns syndrome: a review of the phenotype and diagnostic guidelines. Am J Med Genet A 2004;124:427433.

142 Pereira FA, Tsai MJ, Tsai SY: COUP-TF orphan nuclear receptors in development and differentiation. Cell Mol Life Sci 2000;57: 1388-1398.

143 Kostetskii I, Jiang Y, Kostetskaia E, Yuan S, Evans T, Zile M: Retinoid signaling required for normal heart development regulates GATA-4 in a pathway distinct from cardiomyocyte differentiation. Dev Biol 1999;206:206-218.

144 Li E, Sucov HM, Lee KF, Evans RM, Jaenisch R: Normal development and growth of mice carrying a targeted disruption of the alphal retinoic acid receptor gene. Proc Natl Acad Sci USA 1993;90:1590-1594.

145 Lohnes D, Kastner P, Dierich A, Mark M, LeMeur M, Chambon P: Function of retinoic acid receptor gamma in the mouse. Cell 1993;73:643-658.

146 Lufkin T, Lohnes D, Mark M, Dierich A, Gorry P, Gaub MP, LeMeur M, Chambon P: High postnatal lethality and testis degeneration in retinoic acid receptor alpha mutant mice. Proc Natl Acad Sci USA 1993;90: 7225-7229.

147 Mendelsohn C, Mark M, Dolle P, Dierich A, Gaub MP, Krust A, Lampron C, Chambon P: Retinoic acid receptor beta 2 (RAR beta 2) null mutant mice appear normal. Dev Biol 1994;166:246-258

148 Mayer S, Klaritsch P, Sbragia L, Toelen J, Till H, Deprest JA: Maternal administration of betamethasone inhibits proliferation induced by fetal tracheal occlusion in the nitrofen rat model for congenital diaphragmatic hernia: a placebo-controlled study. Pediatr Surg Int 2008;24:1287-1295.

149 Kantarci S, Casavant D, Prada C, Russell M, Byrne J, Haug LW, Jennings R, Manning S, Blaise F, Boyd TK, Fryns JP, Holmes LB, Donahoe PK, Lee C, Kimonis V, Pober BR: Findings from ACGH in patients with congenital diaphragmatic hernia (CDH): a possible locus for Fryns syndrome. Am J Med Genet A 2006;140:17-23.

-150 Slavotinek A, Lee SS, Davis R, Shrit A, Leppig KA, Rhim J, Jasnosz K, Albertson D, Pinkel D: Fryns syndrome phenotype caused by chromosome microdeletions at 15q26.2 and 8p23.1. J Med Genet 2005;42: $730-736$. 